\title{
PENATAAN KAMPUNG GUJI BARU DENGAN KONSEP KONSOLIDASI TANAH VERTIKAL
}

\author{
Rani Rachmasari ${ }^{1)}$, Suryono Herlambang ${ }^{2)}$, Suryadi Santoso ${ }^{3)}$ \\ 1)Program Studi S1 PWK, Fakultas Teknik, Universitas Tarumanagara, Rani313triple@gmail.com \\ 2)Program Studi S1 PWK, Fakultas Teknik, Universitas Tarumanagara, suryonoh@ft.untar.ac.id \\ 3)Program Studi S1 PWK, Fakultas Teknik, Universitas Tarumanagara, josantosojkt@gmail.com
}

Masuk: 05-08-2021, revisi: 24-08-2021, diterima untuk diterbitkan: 23-10-2021

\begin{abstract}
Abstrak
Pengembangan Infrastruktur Kota Administrasi Jakarta Barat memiliki beberapa rencana seperti rencana pengembangan system pusat kegiatan yang menunjang pelayanan kegiatan dan sebagai pembentuk struktur ruang. Kampung Guji Baru akan diperbaiki dengan Konsep Konsolidasi Tanah Vertikal, karena kampung ini memiliki kondisi yang kurang memenuhi syarat untuk menjadi kawasan yang baik, memiliki lahan yang tidak teratur, dengan konsolidasi lahan maka kampung ini dapat ditata kembali menjadi kawasan yang teratur lengkap dengan prasarana, agar tercapai penggunaan lahan yang secara optimal. Konsep Konsolidasi Tanah dapat menggabungkan secara sistematis lahan yang berpencar-pencar dan tidak teratur disesuaikan dengan tata ruang, mendistribusikan lahan yang telah ada dikonsolidasikan kepada pemilik lahan secara proporsional, mengatur bentuk dan tata letak persil kepemilikan, meningkatkan nilai ekonomis melalui pengadaan sarana dan prasarana lingkungan yang memadai diatas lahan yang disumbangkan oleh pemilik. Konsep ini memiliki prinsip Cost \& Benefit Sharing kepada masyarakat maupun stakeholder terkait seerti pemerintah dan developer. Penyesuaian kembali lahan dalan konsep Konsolidasi Tanah Vertikal sebagi Teknik multiguna dapat memberikan sejumlah manfaat dalam pembangunan perkotaan, termasuk perakitan atau konsolidasi tanah, pembebasan tanah pemerintah untuk tujuan umum, pembangunan infrastruktur, implementasi secara resmi, pembagian baiya dan manfaat yang adil, pendaftaran Analisa tanah, dan pengembangan tanah tepat waktu. Penlitian ini bertujuan untuk menerapkan perbaikan kampung kumuh Guji Baru agar tercipta lingkungan hidup yang baik sesuai rencana tata ruang, menerapkan konsep Konsolidasi Tanah Vertikal.
\end{abstract}

Kata Kunci: GTRA; Konsolidasi Tanah Vertikal; Perbaikan Kampung

\begin{abstract}
Infrastructure Development The West Jakarta Administration has several plans, such as a plan to develop an activity center system that supports activity services and as a spatial structure builderGuji Baru Village will be improved with the Vertical Land Consolidation Concept, because this village has conditions that do not meet the requirements to be a good area, have irregular land, with land consolidation this village can be reorganized into a regular area complete with infrastructure, so that achieve optimal land use. The concept of land consolidation can systematically combine scattered and irregular land according to spatial planning, distribute existing consolidated land to landowners proportionally, regulate the form and layout of ownership parcels, increase economic value through the provision of environmentally friendly facilities and infrastructure. adequate on land donated by the owner. This concept has the principle of Cost \& Benefit Sharing to the community and related stakeholders such as the government and developers. Land readjustment in the concept of Vertical Land Consolidation as a Multipurpose Technique can provide a number of benefits in urban development, including land assembly or consolidation, government land acquisition for public purposes, infrastructure development, legal implementation, fair distribution of costs and benefits, registration Land analysis, and timely land development. This study aims to implement improvements to the Guji Baru slum in order to create a good living environment according to the spatial plan, applying the concept of Vertical Land Consolidation.
\end{abstract}

Key Word: GTRA; Vertical Land Consolidation, Village Improvement 


\section{PENDAHULUAN}

\section{Latar Belakang}

Permasalahan terbatasnya lahan di suatu kota sedangkan kebutuhan rumah terus meningkat membuat pemerintah harus mencari cara untuk mengatasi permasalah tersebut, karena telah banyak kawasan kumuh di Kota Jakarta yang disebabkan permalasahan terebut. Pada Gugus Tugas Reforma Agraria (GTRA) telah mengantongi lokasi yang direncanakan perbaikan kampung kumuh, salah satunya Kampung Guji Baru, Kelurahan Duri Kepa, Kecamatan Kebon Jeruk, Jakarta Barat. Perbaikan kampung ini di usulkan menggunakan konsep Konsolidasi Tanah Vertikal, mengingat lokasi yang tidak cukup luas dan memiliki kepadatan penduduk yang tinggi, juga memiliki aksesbilitas dan proximity yang baik maka kampung tersebut dilihat cocok untuk dapat menerapkan konsep tersebut. Dalam konsep Konsolidasi Tanah prinsipnya yaitu cost $\&$ benefit sharing kepada masyarakat maupun stakeholder terkait seperti pemerintah \& developer. Prinsip yang mendasari penyesuaian kembali lahan adalah pendekatan dari atas ke bawah ke atas yang membutuhkan kerja sama di antara pemilik tanah sehingga terjadi pembagian biaya dan manfaat. Pendekatan partisipasi aktif ini sangat dibutuhkan, jika kebutuhan tanah tinggi tetapi persediaan tanah rendah, seperti di Jakarta. Penyesuaian kembali dapat meningkatkan pendapatan pemerintah daerah dari pajak property, karena nilai tanah meningkat karena dilayani selama proyek penyesuaian kembali tanah. Keuntungan jelas didapatkan oleh kedua belah pihak pemilik tanah dan pihak berwenang. Land readjustment dengan konsep konsolidasi tanah dapat menjadi cara untuk menangani pembangunan tidak terencana yang sedang terjadi. penyesuaian kembali lahan telah diterapkan di banyak negara. Salah satunya di Jepang, pada bulan Maret 2000, sekitar 30\% dari seluruh wilayah perkotaan telah dikembangkan atau dibangun kembali menggunakan metode ini. Keuntungan dan kerugian dari penyesuaian kembali lahan ketika mengupayakan perbaikan pemukiman kumuh dan pembaruan perkotaan, kasus konvesionalnya yaitu Pemerintah Daerah harus menerapkan eminent domain utnuk pembebasan lahan.

\section{Rumusan Permasalahan}

Kampung Guji Baru merupakan kampung yang tergolong padat penduduk sesuai dengan data statistik penduduk, dari kepadatan penduduk tersebut dalam suatu kawasan yang tidak memiliki lahan yang besar maka menimbulkan kekumuhan ditambah dengan kampung berbatasan langsung dengan sungai sekretaris, penduduk Kampung Guji Baru sudah menjadi langganan banjir apabila hujan tiba, banjir tersebut merupakan factor dari kawasan yang tidak memilliki drainase yang baik, juga kondisi rumah rata-rata tergolong dalam rumah semi permanen. Akses dalam kampung dilihat buruk, karena hanya ada satu jalan besar utama itupun tidak dapat dilalui oleh mobil. Permasalahan selanjutnya yaitu seluruh penduduk Kampung Guji Baru tidak memiliki legalitas tanah sesuai dengan peta status lahan BPN dan sumber Kanwil BPN Jakarta Barat.

\section{Tujuan}

Tujuan dari penelitian ini dilakukan yaitu untuk menciptakan lingkungan hidup yang baik sesuai dengan rencana tata ruang, RPJMD, dan GTRA. Dan juga menerapkan konsep konsolidasi tanah vertical yang dirasa cocok untuk perbaikan kampung Guji Baru dan membuat perencanaan penataan di kampung Guji Baru.

\section{KAJIAN LITERATUR}

\section{Kampung}

Kampung merupakan kawasan pemukiman kumuh dengan ketersediaan sarana umum yang buruk atau tidak ada sama sekali, kerap kawasan ini disebut slum. (Budiharjo, 1992). Proses terjadinya kampung merupakan suatu proses yang terjadi dalam waktu yang Panjang. Istilah kampung sudah dikenal sejak pemerintahan Hindia Belanda. Kampung merupakan kawasan permukiman kumuh dengan ketersediaan sarana umum buruk atau tidak ada sama sekali, kerap 
kawasan ini disebut 'slum' dan 'squater' atau juga disamakan dengan permukiman penduduk berpenghasilan rendah (Turner, 1972).

\section{Konsolidasi Tanah}

Konsolidasi tanah adalah kebijakan penataan kembali, penguasaan dan pemanfaatan tanah sesuai rencana tata ruang serta usaha penyediaan tanah untuk kepentingan umum dalam rangka meningkatkan kualitas lingkungan dan pemeliharaan sumberdaya alam dengan melibatkan partisipasi aktif masyarakat. Konsolidasi tanah untuk menata penguasaan pemilikan penggunaan dan pemanfaatan tanah pada ruang atas dan ruang bawah tanah/bumi. Subjek konsolidasi tanah merupakan peserta yang memenuhi syarat yaitu perorangan Warga Negara Indonesia dan/atau Badan Hukum, yang berkedudukan selaku pemegang hak dan penggarap tanah negara.

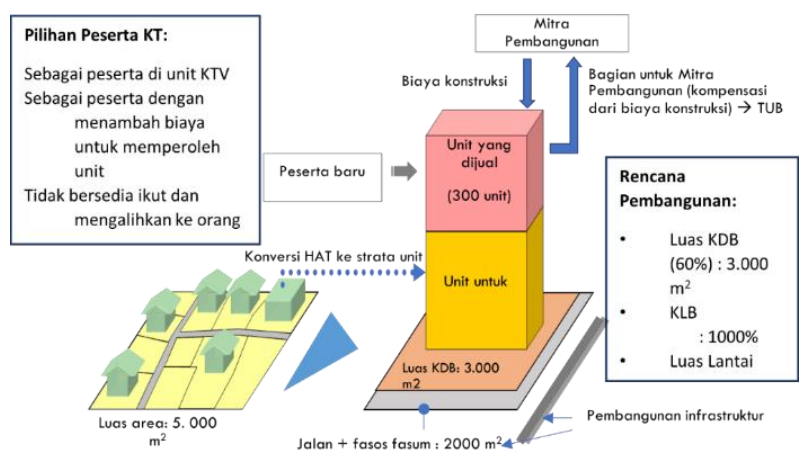

Gambar 1. Ilustrasi Konsolidasi Tanah Vertikal Sumber: Direktorat Konsolidasi Tanah BPN

\section{Rumah Susun}

Rusun merupakan salah satu program nasional untuk mengatasi permaslaahn pemukiman kumuh dan liar. Menurut Undang-Undang Republik Indonesia Nomor 20 Tahun 2011 Tentang Rumah Susun pasal 1 ayat 1, rumah susun adalah bangunan Gedung bertingkat yang dibangun dalam suatu lingkungan, yang terbagi dalam bagian-bagian yang distrukturkan secara fungsional dalam arah horizontal maupun vertical dan merupakan satuan-satuan yang masing-masing dapat dimiliki secara terpisah, terutama untuk hunian, yang dilengkapi dengan bagian bersama dan tanah bersama.

\section{KPBU}

Dasar Kebijakan KPBU adalah Perpres 38/2015 tentang Kerjasama pemerintah dengan Badan Usaha dalam penyediaan infrastruktur sebagai landasan penyelenggaraan KPBU. Kerjasama Pemerintah dengan Badan Usaha memiliki skema yang berbeda dengan skema konvensional biasanya. Berikut adalah skema KPBU:

- Pelaksanaan Kerjasama dituangkan ke dalam kontrak jangka Panjang

- Meminimalisir resiko pelaksanaan proyek

- Kajian aspek resiko

- Ada pembagian resiko

- Bisa digunakan untuk infrastruktur lain

\section{Standar Kebutuhan Rumah Sehat}

Dalam mengetehaui kelayakan lingkungan kampung terdapat standar kebutuhan rumah sehat, yang kemudian didalam standar tersebut terdapat factor minimal ruang yang dibutuhkan per orang dalam satu bidang rumah. Standar tersebut disebutkan pada WHO dan Kemenkes Panduan Kemenkes: 
1. Jauh dari lokasi rawan bencana

2. Bersih dari gas beracun

3. Kualitas tanah yang baik

4. Memiliki sarana dan prasarana penunjang

5. Tidak ada binatang menular

6. Lingkungan harus terdapat penghijauan

7. Bangunan rumah yang sesuai standar

8. Pencahayaan yang baik
9. Suhu udara berkisar $18-30$ derajat Celsius

10. Ventilasi minimal $10 \%$ dari luas lantai

11. Air bersih min 60 liter/hari

12. Memiliki tempat penyimpanan makanan

13. Limbah rumah tidak mencemari air, tanah, bau

14. Kepadatan $\min 8 \mathrm{~m}^{2}$ tiap orang per rumah.

\section{METODE}

Penelitian ini menggunakan metode pengumpulan data primer dan sekunder, dengan dua metode pengolahan data yang pertama berupa metode kualitatif yang didalam nya terdapat metode deskriptif dan kajian kebijakan sector, kemudia yang kedua metode kuantitatif berupa pemetaan social dan analisis potensi kawasan, SWOT, data spasial, programming, visioning. Beberapa metode yang dimasukkan oleh penulis merupakan sumber dari juknis konsolidasi tanah vertical yang tertera dalam tahapan KTV.

\section{DISKUSI DAN HASIL}

Proses perencanaan disesuaikan dengan tahapan yang tertera dalam juknis konsolidasi tanah vertical yang dibuat oleh Direktorat Konsolidasi Tanah BPN, begitu pula data yang dibutuhkan dan analisis yang dilakukan hingga hasil akhir yang di dapat.

\section{Profil Objek Studi}

Lokasi objek studi berada di Kampung Guji Baru, Kelurahan Duri Kepa, Kecamatan Kebon Jeruk Kota Administrasi Jakarta Barat. Kampung Guji Baru memiliki luas lahan sebesar $3.8 \mathrm{Ha}$ terdiri dari RT 004, 005, 006. Delineasi yang ditetapkan merupakan hasil pertimbangan berdasarkan status lahan dikampung tersebut.

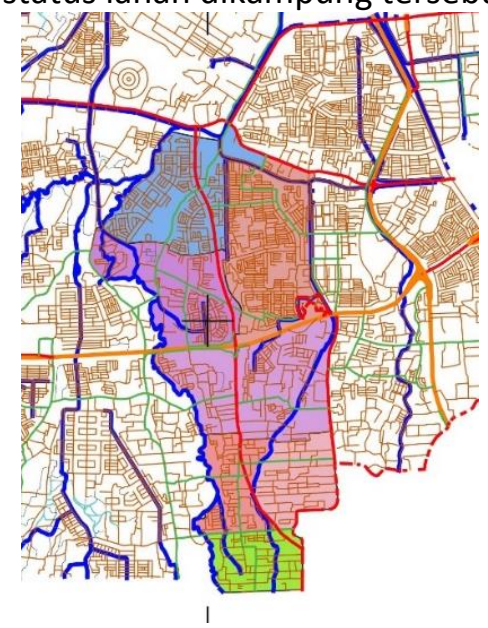

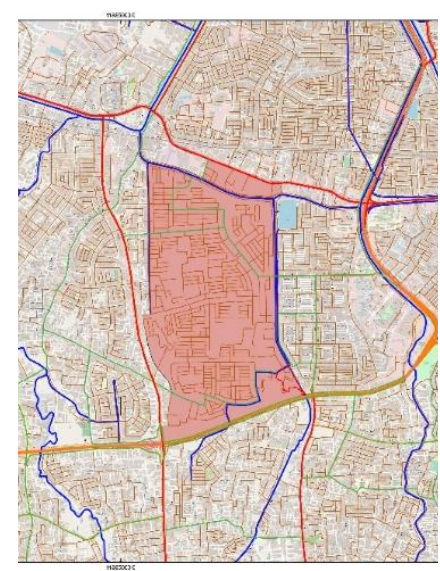

Gambar 2. Peta Kampung Guji Baru Menurut Administrasi

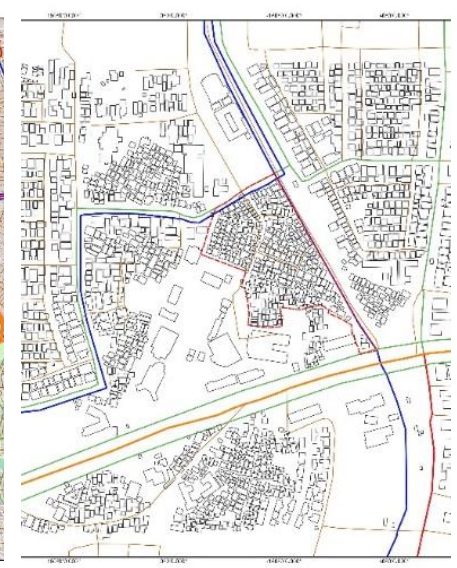

Peta Delineasi Kampung Guji Baru

Sumber: Olahan Penulis

Tapak relatif memiliki bentuk yang tidak teratur sehingga memerlukan perencanaan yang tepat, ukuran tapak dilihat sulit dikembangkan dikarenakan status lahan sekita tapak sudah menjadi hak milik, tapak memiliki 2 muka di bagian utara dan selatan, tapak memiliki banyak akses dari berbagai sisi, akses utama berada di bagian utara. 


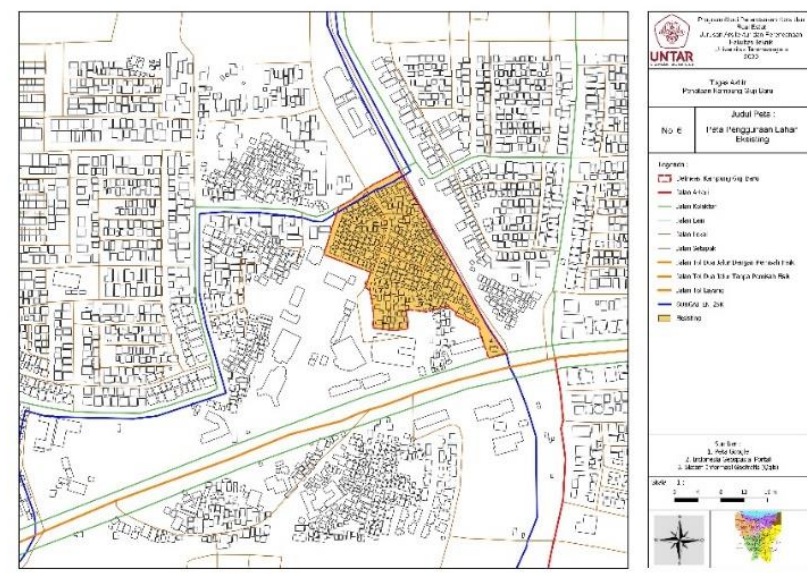

Gambar 3. Peta Penggunaan Lahan di dalam Tapak Sumber : Olahan Penulis

Dilihat dari tabel dibawah rata-rata bidang berbentuk persegi 3191esehat walaupun ada beberapa bidang yang memiliki bentuk persegi dan tidak beraturan. Pada Kampung Guji Baru ini tidak dapat memenuhi syarat rumah sehat dikarenakan memiliki rata-rata jumlah penduduk per bidang cukup tinggi, juga dilihat dari luas lantai kamar tidur memiliki nilai dibawah $8 \mathrm{~m} 2$, sedangkan sesuai dengan Standar Nasional Indonesia (SNI) syarat rumah sehat yaitu jika luas lantai kamar tidur dengan jumlah penghuni menghasilkan diatas $8 \mathrm{~m} 2$ luas lantai per orang.

Tabel 1. Perhitungan Syarat Rumah Sehat

\begin{tabular}{crlrrr}
\hline RT & $\begin{array}{c}\text { Rata-Rata } \\
\text { Luas/m2 }\end{array}$ & Rata-Rata Bentuk & Jml Pddk & $\begin{array}{c}\text { Rata Jml } \\
\text { pddk/bidang }\end{array}$ & $\begin{array}{c}\text { Luas } \\
\text { lantai/org }\end{array}$ \\
\hline 4 & 58.8 & Persegi Panjang & 1384 & 18 & 3 \\
\hline 5 & 68 & Persegi Panjang & 1300 & 12 & 6 \\
\hline 6 & 66 & Persegi Panjang & 980 & 16 & 4 \\
\hline 7 & 63 & Persegi Panjang & 750 & 10 & 6 \\
\hline \multicolumn{2}{l}{ Sumber : Olahan Penulis } & & &
\end{tabular}

\section{Lokasi Objek Studi menurut Peta Pemerintah}

Dalam peta status lahan Kampung Guji Baru terdapat 305 kavling dan seluruhnya tidak memiliki legalitas lahan. Dilihat dari peta tersebut bahwa Kampung Guji Baru seluruhnya tidak memiliki legalitas lahan. Maka dari itu penulis dapat memastikan bahwa delineasi perencanaan akan berada di bagian yang tidak memiliki status lahan tersebut sedangkan bagian yang memiliki status lahan tidak akan masuk dalam delineasi, dikarenakan status lahan tersebut berupa hak milik. 

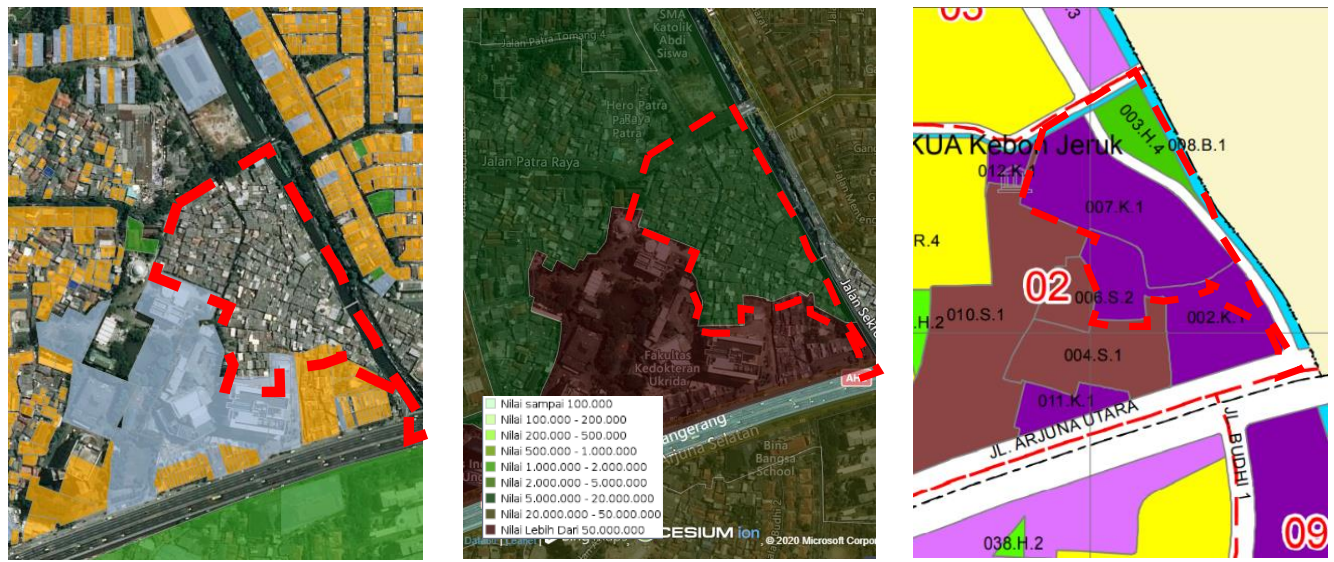

Gambar 4. Peta Pemerintah mengenai Lokasi Objek Studi
Peta Status Lahan
Peta Zona Nilai Tanah
Peta RDTR Jakarta Barat
Sumber : Peta Bhumi ATR/BPN Online dan Peta RDTR Jakarta Barat

Dalam peta zona nilai tanah tertera bahwa Kampung Guji Baru termasuk dalam zona 64 dengan rentang nilai harga Rp.5.000.000 hingga Rp.10.000.000. Tapak terletak pada Kelurahan Duri Kepa Kecamatan Kebon Jeruk Blok 02, Sub Blok 007 \& 002 yaitu tepatnya Zona Perkantoran, Perdaganagn dan Jasa Sub Zona K.1 > Sub Zona Perkantoran, memiliki KDB 55 / 60, KLB 2.4 / 3, KB 4 / 8, KDH 30 / 30, KTB 55 / 55, Tipe T / T, PSL P (Padat) / P (Padat). Tapak terletak pada zona perkantoran, perdagangan dan jasa yang membuat tapak ini berpotensi dikembangkan untuk beragam fungsi. Intensitas bangunan yang diperbolehkan untuk lahan ini mendukung untuk dibangun bangunan middle rise dengan fungi campuran namun dengan fungsi utama komersial.

\section{Aksesibilitas Objek Studi}

Transportasi umum yang tersedia untuk melayani akses menuju Kampung Guji Baru terbagi menjadi beberapa jenis, yaitu:

1. Transportasi angkutan massa tersedia angkutan umum (angkot B07A dan B03), bus kecil transjakarta (JAK30)

2. Transportasi angkutan online (grab, gojek, taxi)

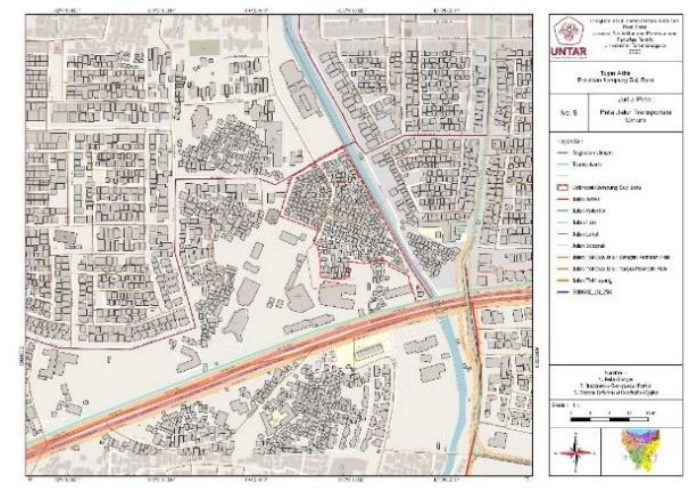

Gambar 5. Peta Jalur Transportasi Umum Sumber: Openstreetmap dan Olahan Penulis

Memiliki akses jalan besar yang cukup baik yaitu Jl Arjuna Utara yang berada tepat sejalur dengan Tol Jakarta - Merak. Dekat dengan beberapa gerbang tol, sekitar $1.3 \mathrm{~km}$ dengan gerbang tol Tomang dan 1.5 km dengan gerbang tol Kebon Jeruk. Secara administrasi Kampung Guji Baru dilintasi oleh beberapa kelas jalan, yaitu: 


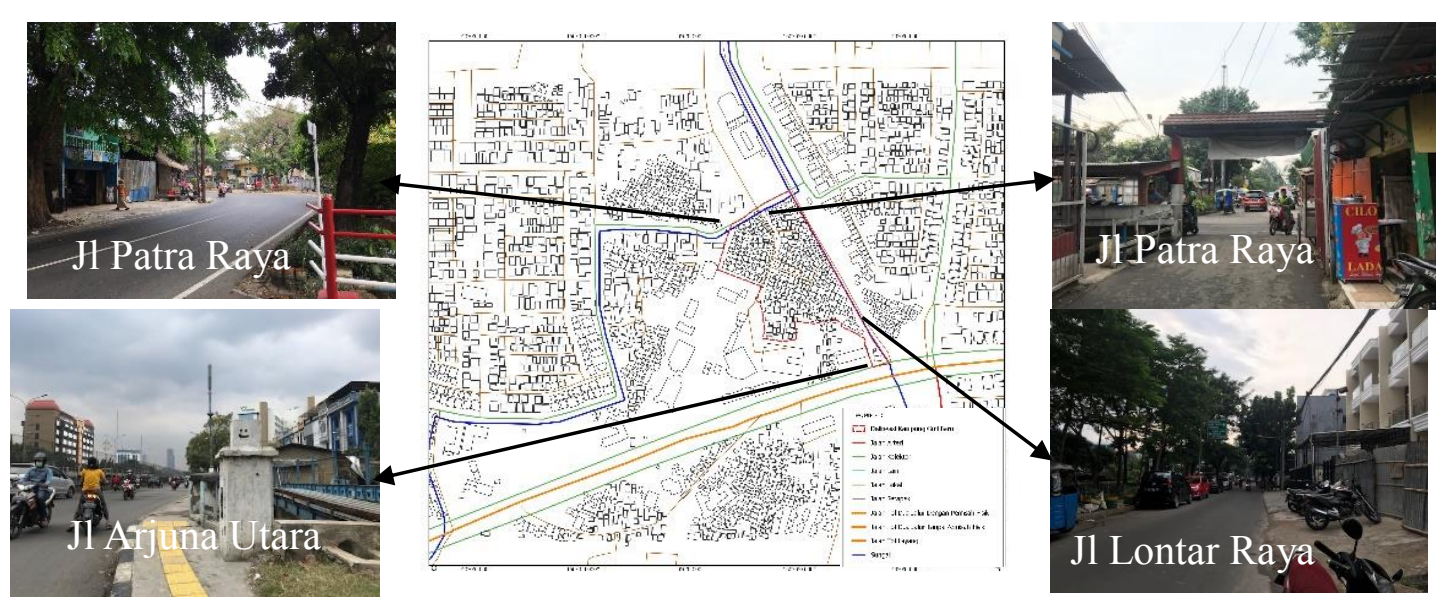

Gambar 6. Posisi Objek Studi Kampung Guji Baru

Sumber : Dokumentasi dan Olahan Penulis

Jaringan jalan disekitar objek studi cukup beraneka ragam dan untuk suatu permukiman yang tergolong dalam klasifikasi kumuh jaringan jalan sekitarnya cukup baik. Memiliki muka lahan yang berhadapan langsung dengan jalan utama yaitu Jl. Arjuna Utara dan Jl. Patra Raya.

\section{Proximity}

Kampung Guji Baru mempunyai kedekatan dengan beberapa kawasan pusat kegiatan seperti Podomoro City, CBD Jakarta Barat

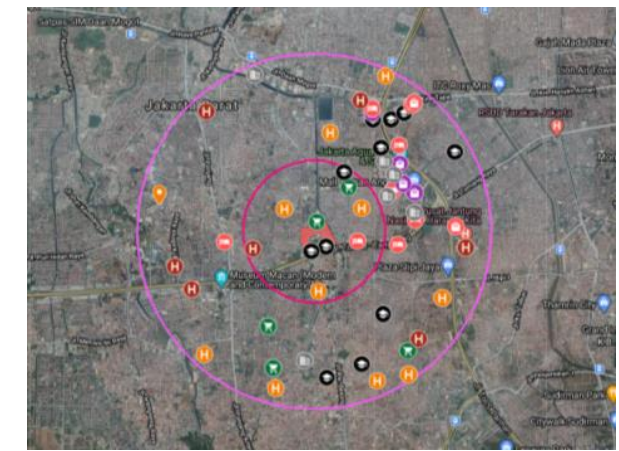

Gambar 7. Proximity dengan Radius $2.5 \mathrm{Km}$ Sumber : Olahan Penulis

Dari informasi diatas dapat dilihat bahwa sekitar Kampung Guji Baru cukup banyak pusat kegiatan dari mall, rumah sakit, kantor hingga apartemen. 
Tabel 2. Proximity Area Vital dengan Kampung Guji Baru

\begin{tabular}{|c|c|c|c|}
\hline \multirow[t]{2}{*}{ Nama Area } & \multirow[t]{2}{*}{ Jarak } & \multicolumn{2}{|l|}{ Waktu Tempuh } \\
\hline & & Dari Kampung Guji Baru & Menuju Kampung Guji Baru \\
\hline $\begin{array}{l}\text { Stasiun Tanah } \\
\text { Abang }\end{array}$ & $6.5 \mathrm{Km}$ & $\begin{array}{l}15 \text { Menit (Jl Letjen S } \\
\text { Parman) }\end{array}$ & 16 Menit \\
\hline $\begin{array}{l}\text { Bandara Soekarno } \\
\text { Hatta }\end{array}$ & $26 \mathrm{Km}$ & $\begin{array}{l}31 \text { Menit (JI. Tol Airport } \\
\text { Prof. Sedyatmo } \\
\text { ) }\end{array}$ & $\begin{array}{l}30 \text { Menit (Jl. Tol Airport Prof. } \\
\text { Sedyatmo } \\
\text { ) }\end{array}$ \\
\hline $\begin{array}{l}\text { Bandara Halim } \\
\text { Perdana Kusuma }\end{array}$ & $20 \mathrm{Km}$ & $\begin{array}{l}39 \text { Menit ( Tol Cawang- } \\
\text { Grogol) }\end{array}$ & 33 Menit ( Tol Cawang-Grogol) \\
\hline Terminal Grogol & $3.5 \mathrm{Km}$ & $\begin{array}{l}12 \text { Menit (Jl. Letjen S } \\
\text { Parman) }\end{array}$ & 16 Menit (JI. Letjen S Parman) \\
\hline CBD Puri Indah & $4.9 \mathrm{Km}$ & $\begin{array}{l}13 \text { Menit (Jl Kedoya } \\
\text { Raya) }\end{array}$ & 14 Menit (JI Puri Indah Raya) \\
\hline $\begin{array}{l}\text { Komplek Agung } \\
\text { Podomoro }\end{array}$ & $2.7 \mathrm{Km}$ & $\begin{array}{l}10 \text { Menit (JI Tanjung } \\
\text { Duren Raya) }\end{array}$ & $\begin{array}{l}12 \text { Menit ( Jl Tanjung Duren } \\
\text { Raya) }\end{array}$ \\
\hline $\begin{array}{l}\text { Sudirman Central } \\
\text { Business District }\end{array}$ & $9.2 \mathrm{Km}$ & $\begin{array}{l}24 \text { Menit (JI Letjen S } \\
\text { Parman) }\end{array}$ & 19 Menit (JI Letjen S Parman) \\
\hline
\end{tabular}

Sumber : Olahan Penulis,2021

\section{Analisis Pasar}

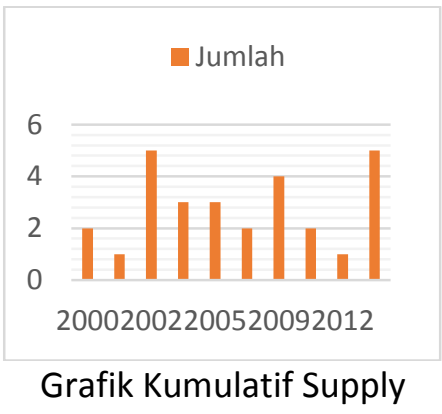



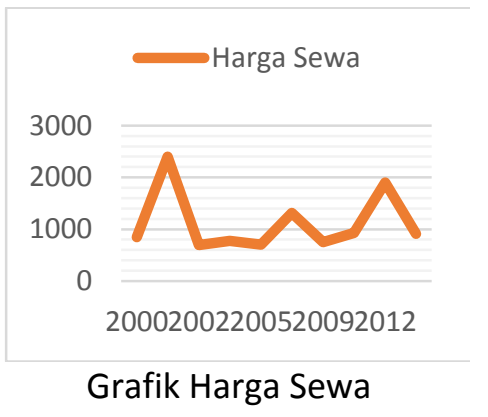

Dari grafik kumulatif supply dapat dilihat bahwa supply ruko melonjak ditahun 2002, kemudian menurun dan stabil di tahun 2004 - 2005 dan turun kembali pada tahun 2007. Lalu terjadi kenaikan supply ruko di tahun 2009 dan turun kembali hingga tahun 2012.

Dilihat dari grafik harga jual ruko dalam radius $5 \mathrm{~km}$ paling tinggi ada di tahun 2001 seharga 24 miliar rupiah (Ruko Roxy Mas), harga jual terendah berada di tahun 2002 seharga 1.3 miliar rupiah (ruko maisonet), rata-rata harga jual ruko yang telah penulis catat yaitu sebesar 9 miliar rupiah. Dari grafik harga sewa dapat dilihat bahwa harga sewa ruko beriksar $10 \%$ dari harga jual.

\section{Kondisi Sekitar Tapak}

Dapat dilihat pada peta diatas kondisi sekitar tapak dikelilingi oleh bangunan landed maupun vertical, mayoritas fungsi lahan adalah hunian tapak, terdapat juga fungsi komersial, fasilitas, dan industri 


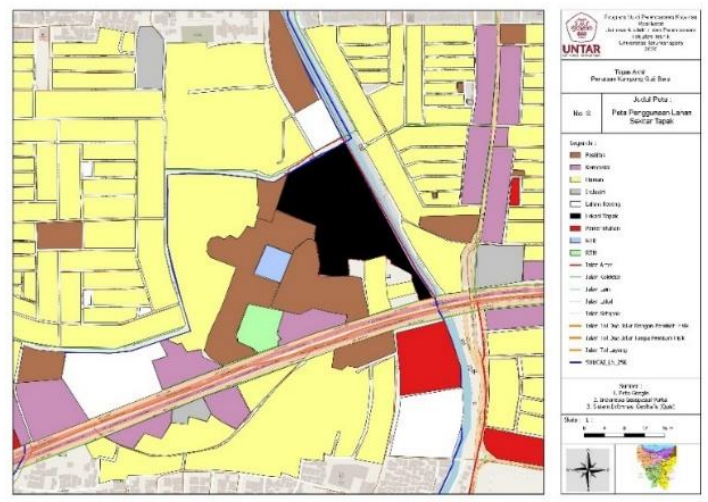

Gambar 8. Peta Penggunaan Lahan Sekitar

Sumber : Olahan Penulis

\section{Penduduk}

Jumlah penduduk dilihat dari total jumlah kepala keluarga yang ada di Kampung Guji Baru. Berikut perhitungan kasaran proyeksi penduduk atau bisa disebut sebagai programming.

Tabel 3. Kepadatan Penduduk

\begin{tabular}{cccccccc}
\hline No & RT & $\begin{array}{c}\text { Luas } \\
(\mathrm{Ha})\end{array}$ & $\begin{array}{c}\text { Jumlah } \\
\text { Bangunan }\end{array}$ & $\begin{array}{c}\text { Jumlah } \\
\text { KK }\end{array}$ & $\begin{array}{c}\text { Jumlah } \\
\text { Penduduk }\end{array}$ & $\begin{array}{c}\text { Kepadatan } \\
\text { Penduduk }\end{array}$ & Klasifikasi \\
\hline 1 & 4 & 0.9 & 74 & 511 & 1384 & 1537.78 & Sangat Padat \\
\hline 2 & 5 & 1.1 & 106 & 400 & 1300 & 1181.82 & Sangat Padat \\
\hline 3 & 6 & 0.9 & 68 & 220 & 980 & 1088.89 & Sangat Padat \\
\hline 4 & 7 & 1 & 68 & 315 & 750 & 750.00 & Sangat Padat \\
\hline $\begin{array}{c}\text { Jumlah / } \\
\text { Total }\end{array}$ & 3.9 & 316 & 1446 & 4414 & 1131.79 & Sangat Padat \\
\hline
\end{tabular}

Sumber : Data BPS dan Olahan Penulis,2021

Total dari data diatas kampung Guji Baru memiliki 4414 jiwa penduduk dengan total 1446 kepala keluarga dan memiliki total kepadatan penduduk 1132 sesuai dengan standar SNI maka penduduk Kampung Guji Baru dapat diklasifikasikan sangat padat.

\section{Perhitungan Nilai Perbandingan Konversi (NPK)}

Kesimpulan dari perhitungan diatas yaitu nilai tanah total dari RT $04,05,06,07$ sesuai Zona Nilai Tanah yaitu sebesar Rp.127.695.000.000 sedangkan jika berdasarkan NJOP nilai tanah sebesar Rp.70.972.881.000 dan berdasarkan nilai tanah market value sebesar Rp.177.432.202.500. Nilai bangunan berdasarkan NJOP yaitu Rp.62.417.316.000 sedangkan nilai bangunan market value sebesar Rp.4.435.805.063. Nilai asset yang didapat dari scenario konversi 1 sebesar Rp.190.112.316.000 sedangkan pada scenario konversi 2 sebesar 181.868.007.563. Skenario Nilai Perbandingan Konversi peserta konsolidasi tanah opsi 1 memiliki nilai 0.45 sedangkan untuk opsi 2 memiliki nilai 0.43. dalam perhitungan scenario jumlah sarusun peserta konsolidasi tanah Kampung Guji Baru pada opsi 1 mendapat jumlah sarusun 642 sedangkan pada opsi 2 mendapat jumlah sarusun 614

\section{Perhitungan Kebutuhan Ruang}

Besaran ruang diperoleh dari studi besaran ruang dengan menggunakan beberapa buku literatur. Literatur ini digunakan sebagai acuan untuk mendapatkan standar minimal kelayakan sebuah bangunan rumah susun dan ruang-ruang di dalamnya standar tersebut diperoleh dari beberapa studi letratur dan banding, antara lain: 
- $\quad$ SNI : Standar Nasional Indonesia

- PRS : Pedoman Perencanaan dan Perencanaan Pembangunan Rumah Susun (Draft Ke-III) JICA secretary/Perum Perumnas

Perbedaan lahan ini terletak pada pembagian bangunan untuk zona lahan efektif, penulis mengasumsikan dengan melihat konsep pembangunan rumah susun dan berdasarkan data RDTR yang ada bahwa bangunan tersebut harus memiliki sekiranya 60\% KDB. Pembagian zona tersebut diasumsikan pembagian $1 / 3$ dari luas lahan efektif untuk diserahkan atau menjadi bagian developer sebagai pengembang.

$\mathrm{KDB}=60 \%$

$\mathrm{KLB}=3$

Luas lahan $=3,8 \mathrm{Ha}$ atau $38.000 \mathrm{~m}^{2}$.

Berikut perhitungan berdasarkan KDB dan KLB yang diterapkan :

$$
\begin{gathered}
\frac{1}{3} \text { Luas Lahan }=\text { Luas Lahan Asumsi } \\
\frac{1}{3} 38000=26000 \mathrm{~m}^{2}
\end{gathered}
$$

Didapat luas lahan asumsi sebesar 2,6 Ha atau $26000 \mathrm{~m}^{2}$. Berikut perhitungan berdasarkan KDB dan KLB yang diterapkan :

$$
\begin{gathered}
\text { Luas Efektif }=\text { Luas Lahan Asumsi } x \text { KDB } \\
26000 \times 60 \%=15600 \mathrm{~m}^{2}
\end{gathered}
$$

Didapat luas efektif dari perhitungan KDB sebesar $15.600 \mathrm{~m}^{2}$.

Untuk perhitungan, penulis mengambil beberapa asumsi untuk mendapatkan keseluruhan luas kebutuhan ruang yang ada pada tapak objek studi dan berapa kebutuhan unit yang harus disediakan didalam tapak objek studi, dari data jumlah kepala keluarga penulis mengasumsikan bahwa jumlah kepala keluarga tersebut dapat diasumsikan sebagai jumlah unit yang dibutuhkan. Berikut perhitungan kebutuhan unit berdasarkan jumlah kepala keluarga yang ada: Luas lahan efektif $=15.600 \mathrm{~m}^{2}$. Jumlah penduduk $=4414$ jiwa Jumlah kk/unit = $1446 \mathrm{kk} / \mathrm{unit}$ Standar ukuran rumah susun minimal $18 \mathrm{~m} 2$ dan paling besar adalah $50 \mathrm{~m} 2$. Berikut ukuran rusun:

- Tipe 18, 21, $24 \mathrm{~m} 2$ = 1 kamar tidur, ruang tamu/keluarga, kamar mandi, dapur

- Tipe 30, 36, 42, 50m2 = 2 kamar tidur, ruang tamu/keluarga, ruang makan, kamar mandi, dapur

Penulis mengasumsikan ukuran unit rumah susun sebesar $6 \times 5$ atau $30 \mathrm{~m} 2$. Sedangkan untuk luas lantai dasar rumah susun per tower diasumsikan $55 \times 14$ yaitu sebesar $770 \mathrm{~m} 2$. Berikut perhitungan jumlah unit yang dibutuhkan berdasarkan ukuran unit yang telah diasumsikan :

Ukuran unit rumah susun $=30 \mathrm{~m} 2$

Jumlah kebutuhan unit $=1446$ unit

Luas lantai dasar $=770 \mathrm{~m} 2$

$\mathrm{KB}=8$ lantai

Jumlah unit/lantai $=22$ unit

22 unit $x 8$ lantai $=176$ Unit

Total unit/tower $=176$ unit

Jumlah Kebutuhan Unit : Total unit tower = Jumlah Kebutuhan Tower

$1446: 176=8$ Tower

Jumlah Tower $x$ Luas Lantai Dasar = Luas Kebutuhan Tower

$8 \times 770=6160 \mathrm{~m} 2$

Luas total lantai dasar $=6160 \mathrm{~m} 2$

$$
15600-6160=9440 m 2
$$


Dari perhitungan diatas didapat luas total lantai dasar untuk rumah susui sebesar $6160 \mathrm{~m} 2$. Kemudian penulis sudah mengasumsikan bahwa developer telah mendapat bagian lahan $1 / 3$ dari total lahan yaitu sebesar $1.2 \mathrm{Ha}$ atau sekitar $12000 \mathrm{~m} 2$. Dari luas total lantai dasar diatas didapat sisa dari lahan efektif yaitu sebesar $9440 \mathrm{~m} 2$, penulis asumsikan lahan sisa tersebut akan digunakan untuk fasilitas dan akses.

\section{Konsep dan Rencana}

Disini penulis menuturkan hasil desain rencana penataan yang telah dibuat pada bab ini, melihat dari segi kondisi eksisting, analisis tapak dan analisis kebutuhan ruang dan berdasarkan kebijakan perencananaan Konsolidasi Tanah yang akan dimasukkan kedalam suatu keluaran produk yaitu Masterplan.

\section{Skenario Pembebasan Lahan}

Akan dilakukan pembebasan diseluruh lahan seluas $3.8 \mathrm{Ha}$, dimana ada sekitar 316 bangunan hunian yang diisi sekitar 4114 jiwa tergusur. Namun pembebasan lahan ini sudah menjadi pertimbangan penulis berdasarkan pasar dan aksesibilitas sekitar lahan yang dapat mendukung Konsep Konsolidasi Tanah dan menambah nilai tanah di Kampung Guji Baru. Selain itu ada jalan umum yang dipertahankan, yaitu Jl Patra Tomang Raya yang pada eksistingnya merupakan jalan utama kampung sepanjang $183.835 \mathrm{~m}$, kemudian pada rencana penataan jalan tersebut akan di perlebar, karena pada eksisting sebelumnya jalan utama itu tidak dapat dimasuki mobil, sedangkan pada rencana penataan dibuat pelebaran jalan agar dapat dilalui oleh motor dan mobil.

\section{Rencana dan Konsep Penataan}

Terdapat 2 blok dalam konsep perencanaan yaitu blok rumah susun dan blok komersial. Blok komersial yang dibuat diisi dengan unit ruko sesuai dengan analisis pasar di bab sebelumnya, karena pasar sekitarnya didominasi oleh ruko maka penulis memutuskan blok komersial tersebut akan diisi dengan ruo, untuk menarik minat pengembang.

1. Blok Rumah Susun

Dari 2 blok rumah susun di masing-masing blok terdapat 4 tower rusun 8 lantai dengan jumlah unit masing-masing tower adalah 160 unit dengan luas masing-masing tower yaitu $770 \mathrm{~m} 2$, maka total luas tower yang ada di masing-masing blok tersebut yaitu $3.080 \mathrm{~m} 2$.

2. Blok Komersial

Terdapat 2 blok komersial dengan jumlah ruko yang berbeda di masing-masing blok tersebut. Pada blok komersial pertama terdapat 54 ruko dengan ukuran $4 \times 15$ atau sekitar $60 \mathrm{~m} 2$, dalam blok komersial pertama tersebut terdapat ukuran ruko yang berbeda karena penulis sesuaikan dengan bentuk blok yang ada. Kemudian pada blok komersial kedua terdapat 18 unit ruko dengan ukuran $4 \times 15$ atau $60 \mathrm{~m} 2$.

\section{Rencana Penggunaan Lahan pada Tapak}

Dari gambaran dibawah penulis menetapkan penzonasian, dimana fasilitas yang disediakan penulis berupa Ruang Terbuka Hijau, penentuan fasilitas ini juga berdasar pada lingkungan yang ada disekitarnya, yaitu kebutuhan area RTH sesuai dengan peta Rencana Detail Tata Ruang (RDTR). Selain itu terdapat tambahan zonasi komersial campuran berupa ruko dimaksudkan untuk menarik pengembang dan menaikkan harga lahan di lokasi tersebut. 

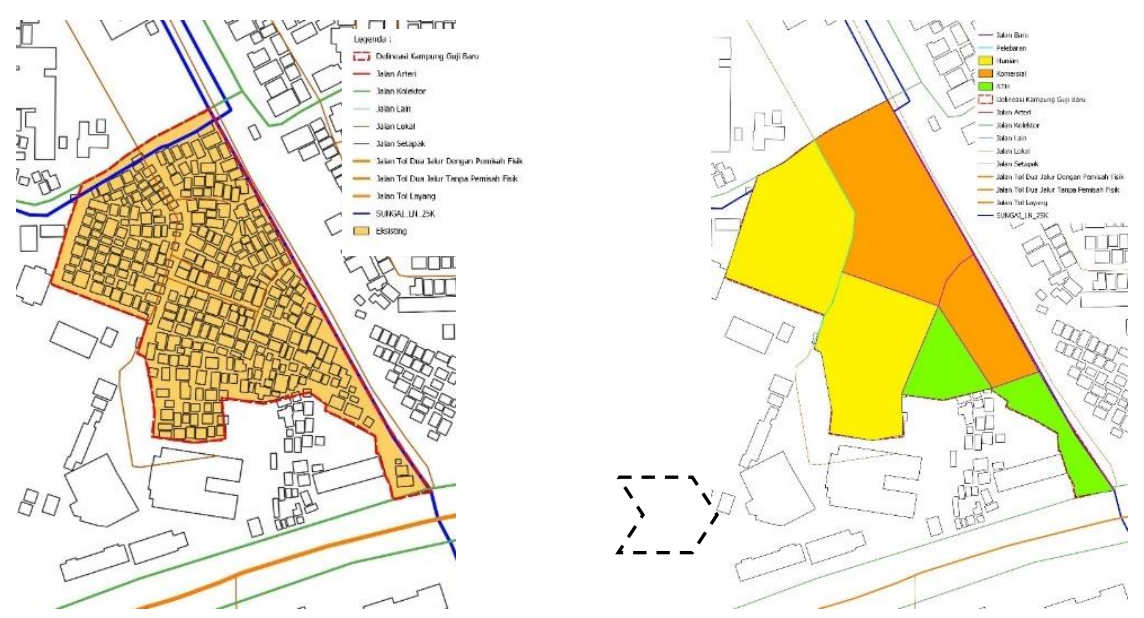

Gambar 10. Peta Komparasi Penggunaan Lahan

Gambar Peta Penggunaan Lahan Eksisting

Gambar Peta Penggunaan Lahan

Rencana

Sumber : Olahan Penulis
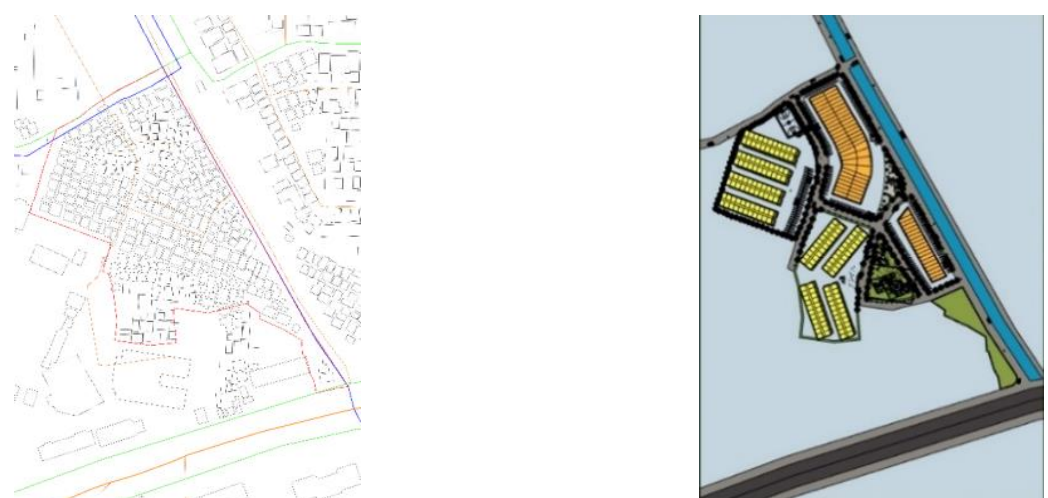

Gambar 11. Peta Komparasi Eksisting dan Konsep Peta Eksisting Peta Masterplan Rencana Sumber : Olahan Penulis

Dari gambar diatas dapat dilihat bahwa penulis menyesuaikan semua desain rencana dengan melihat kondisi disekitar tapak. Penulis merombak penuh kampung dikarenakan lahan yang terbatas dan kebutuhan tempat tinggal yang tinggi juga bentuk tapak yang tidak tertata dan perlu diingat pula bahwa status lahan pada delineasi yang penulis tetapkan tidak memiliki legalitas lahan, perlu diketahui bahwa tanah tersebut merupakan tanah negara.

\section{Ilustrasi Kawasan}

Berikut ilustrasi kawasan yang penulis bentuk kedalam bentuk sketchup dan enscape render.

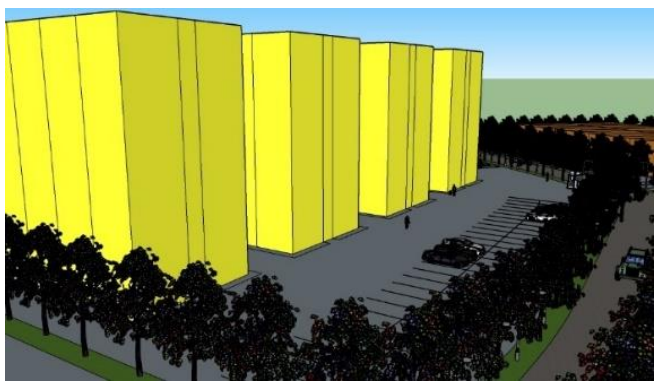

3D Tampak Rusun 1

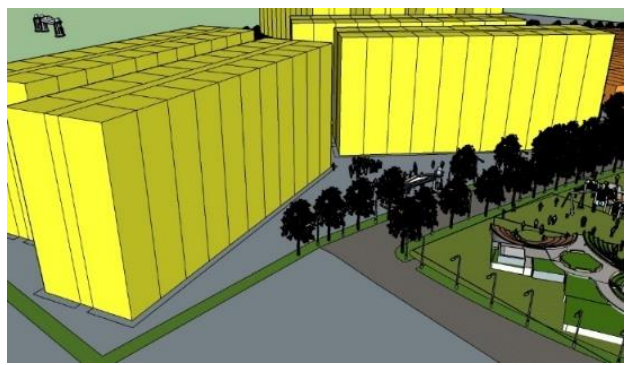

3D Tampak Rusun 2 


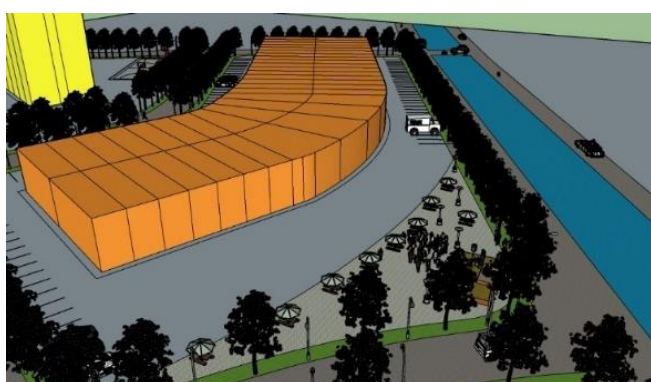

3D Tampak Komersial 1

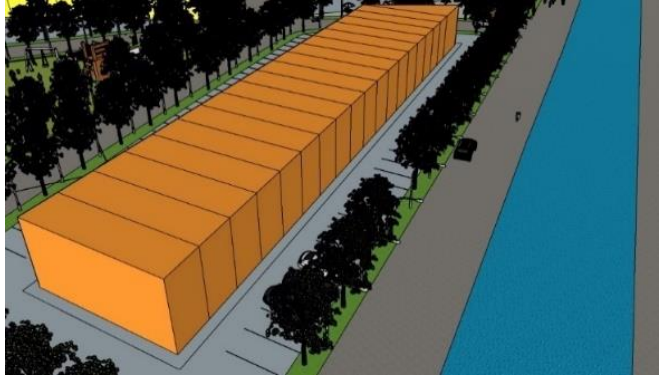

3D Tampak Komersial 2

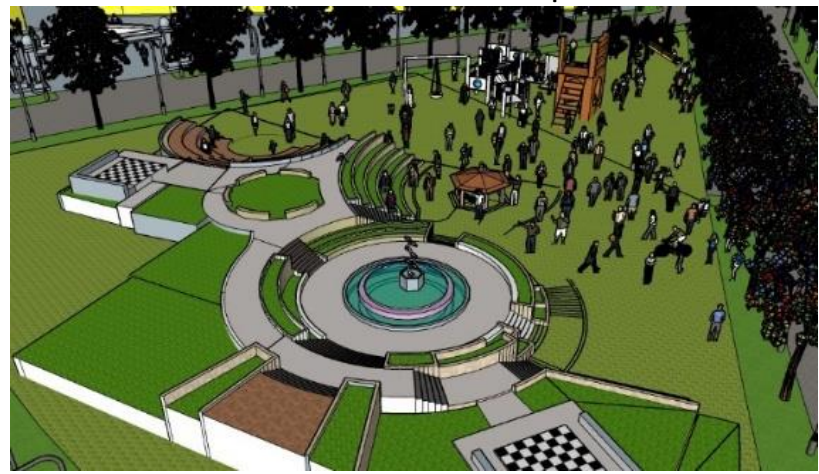

3D Ruang Terbuka Hijau

Gambar 12. Ilustrasi Rencana Penataan Kampung Guji Baru Sumber : Olahan Penulis

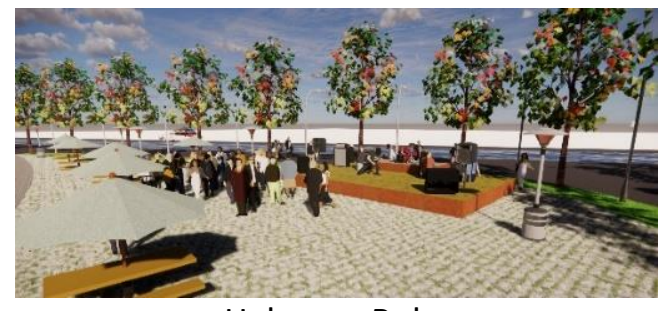

Halaman Ruko

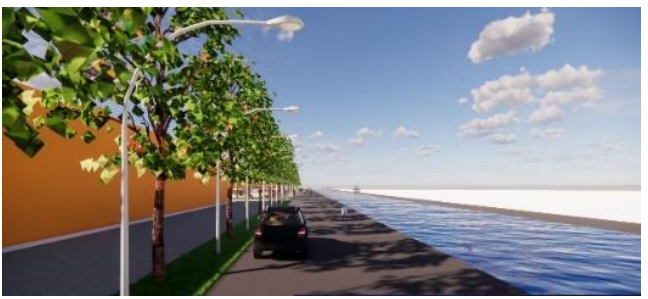

Jl Baru Komersial

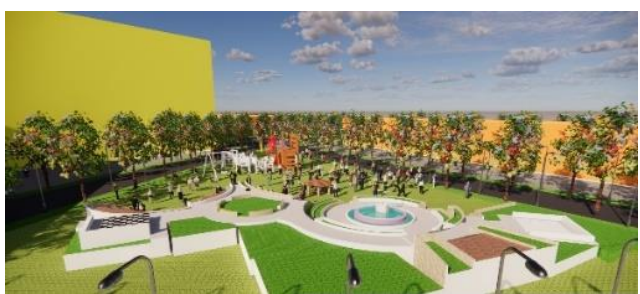

Ruang Terbuka Hijau

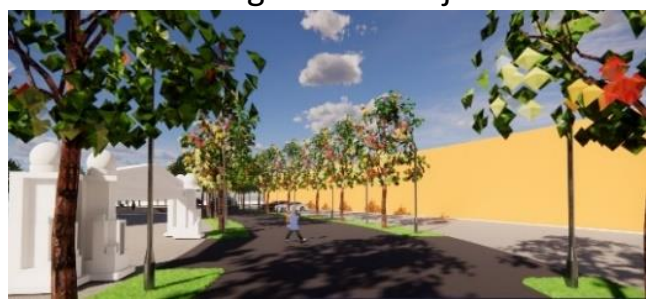

Jl Patra Tomang Raya



Jl Samping RTH

Gambar 13. 3D Render Enscape

Sumber : Olahan Penulis 


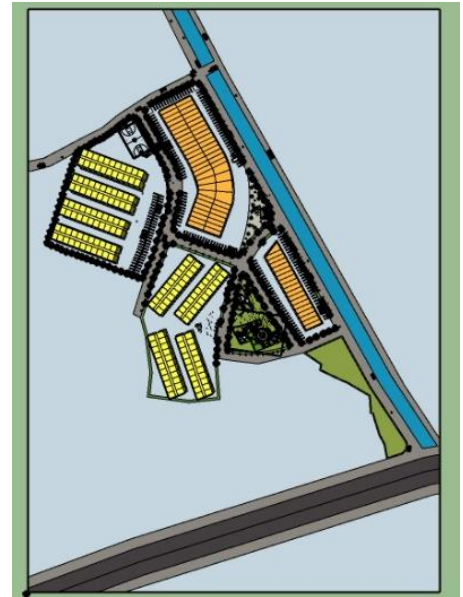

3D Tampak Atas Sketch Up

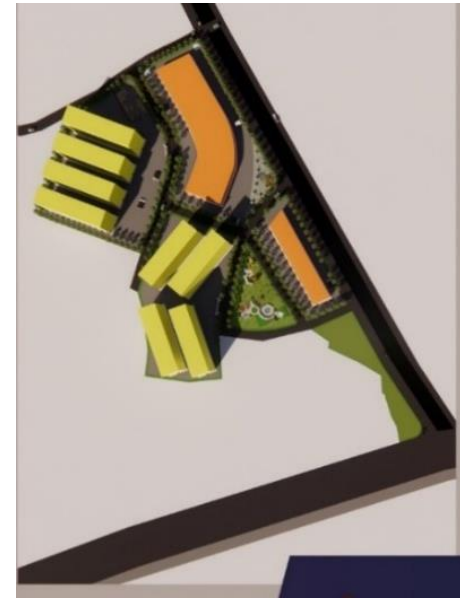

3D Tampak Atas Enscape

Gambar 14. Komparasi 3D

Sumber : Olahan Penulis

\section{KESIMPULAN DAN SARAN}

\section{Kesimpulan}

Kampung Guji Baru seluruh bidangnya tidak memiliki legalitas lahan, dapat disimpulkan bahwa lahan tersebut merupakan lahan milik negara dijadikan tempat tinggal oleh penduduk. Lahan yang terbatas dan banyaknya jumlah penduduk maka lahan negara tersebut dijadikan tempat tinggal kumuh, karena berlokasi di samping sungai sekretaris, kekumuhan pun tidak dapat dihindari.

Kampung ini tidak memiliki fasilitas yang menunjang kebutuhan masyarakat. Penentuan konsep Konsolidasi Tanah Vertikal dilihat dari kondisi eksisting, aksesibilitas dan pasar disekitar kampung. Jurnal ini berdasarkan tahapan KTV dan mengupayakan keuntungan ketiga pihak (masyarakat, pemerintah, developer).

Data penduduk yang didapat maka didapat jumlah unit yang dibutuhkan untuk membuat rencana pembangunan rusun. Nilai aset rata-rata bidang sekitar Rp.400.000.000, nilai NPK dilihat sangat kecil rata-rata bidang memiliki nilai 0.0002 disimpulkan tidak ada pemilik bidang yang mendapatkan jatah ruko yang direncanakan. Blok komersial ruko diperuntukan untuk pengembang. Jika pengembang yang tertarik akan mendapatkan 2 blok komersial, dengan ratarata harga jual Rp.5.000.000.000. Pada rencana konsep terdapat jalan baru disamping sungai sekretaris langsung menuju blok komersial dan melebarkan jalan eksisting utama dalam kampung yaitu Jl. Patra Tomang, pada akhirnya jalan tersebut merupakan jatah Pemerintah Daerah.

\section{Saran}

Sebaiknya pemerintah melihat permasalahan dan juga potensi yang ada di kampung ini, sehingga kampung kumuh ini bisa dibuat perencanaan untuk mengembangkan kampung maupun kawasan disekitarnya. Terkait dengan GTRA dan konsep yang dipilih, maka pemerintah perlu mempertimbangkan cara perbaikan kampung dari penelitian ini. Dari konsep konsolidasi tanah yang dipakai, dapat menaikan harga lahan dan masuknya developer dapat mengembangkan lokasi dan kawasan disekitarnya dalam pembangunan ruko yang tertera di laporan ini. Rekomendasi rencana penataan kampung ini tampilkan untuk menarik hati pengembang untuk datang dan bekerja sama dengan menciptakan kawasan kampung kumuh lebih tertata dan menghilangkan kekumuhan di DKI Jakarta. 


\section{REFERENSI}

Fitria, N., dan Setiawan, R. P. (214). JURNAL TEKNIK POMITS. Identifikasi Karakteristik Lingkungan Permukiman Kumuh di Kelurahan Kapuk,Jakarta Barat, 1-5.

Heryati. (2011). S.Ars. KAMPUNG KOTA SEBAGAI BAGIAN DARI PERMUKIMAN KOTA, 1-13.

Iwan Kustiwan, A. R. (2019). Strategi Peningkatan Kualitas Lingkungan Kampung-Kota.

Menteri Agraria dan Tata Ruang dan Kepala Badan Pertanahan Nasional. (2019). Konsolidasi Tanah (12). Jakarta

Mulyanti, W. (2015). Pengaruh Konsolidasi Lahan Perkotaan terhadap Harga Tanah di Ringintelu, Kelurahan Kalipancur - Kota Semarang. Jurnal Pembangunan Wilayah \& Kota, $67-75$.

Nurlinda, I. (2010). Jurnal Hukum. Metode Konsolidasi Tanah untuk Pengadaan Tanah yang Partisipasif dan Penataan Ruang yang Terpadu, 6-13.

Schrock, M. (2012). Thesis. The Potential Use of Land Readjustment as an Urban Redevelopment Strategy in the United States: Assessing Net economic Value, 29 -77.

Studies, R. C. (2018). DKI Jakarta: Rujak Centre for Urban Studies.

Supriatna, A. (2011). Thesis. The Feasibility Study Of Land Readjustment For Kampung Upgrading in Jakarta, 11-55.

Supriatna, A. (2013). Land Readjustment As A Spatial Planning Tool For Kampung Upgrading. Germany: LAP Lambert Academic Publishing.

Supriatna, A. (2013). Land Readjustment As Spatial Planning Tool For Kampung Upgrading. Germany: LAP Lambert Academic Publishing.

Supriatna, A. (2017). Disertasi. Analysing Land Tenure Security of Urban Kampung in Jakarta, $22-190$.

Supriatna, A. (2018). Land Readjustment for Upgrading Indonesian Kampung. Netherlands.

Tanah, D. K. (2019). Rakernis. Jakarta.

Weiming Tong, Kevin Lo, Pingyu Zhang. (2020). Land Consloidation in Rural China : Life Satisfaction among Resettlers and Its Determinants. Land, 4 - 13.

Winarso, H. (2016). Orasi Ilmiah. Penyediaan Lahan untuk Perumahan dan Permukiman di Perkotaan Menggunakan Skema KPBUM, 11-16.

Winarso, H. (2020). FGD Bappenas. Penyediaan Lahan untuk Perumahan dan Permukiman di Perkotaan Menggunakan Skema KPBUM, 4-44. 
